\title{
KAJIAN PENGETAHUAN GURU MENGENAI INTERNET SEBAGAI SALAH SATU SUMBER REFERENSI DALAM PENYUSUNAN KARYA TULIS ILMIAH
}

\author{
Desak Putu Eka Nilakusmawati \\ FMIPA Universitas Udayana (koyas_pt@yahoo.com; HP. 081936227301)
}

\begin{abstract}
A Study on Teachers' Knowledge of the Internet as a Reference Source for Scientific Papers. This study aims to investigate the prior knowledge of the teachers of SMPN 3 Tabanan, Tabanan Regency, concerning the internet as one of the reference sources for scientific papers and to analyze the effectiveness of training in the improvement of their knowledge of ways to search references through the internet. This study was a pre-experimental study employing the pretest and posttest group design. The data were collected using a pretest and a posttest. Training was conducted on ways to search references for scientific papers, employing presentation and demonstration. The research hypothesis was tested using a paired sample t-test. The results of the analysis show a t-test value of -14.258 $(\mathrm{p}<.01)$, indicating that the training is effective to improve the participants' knowledge of ways to search references for scientific papers through the internet.
\end{abstract}

Keywords: teacher's knowledge, the internet, reference sources

\section{PENDAHULUAN}

Ketentuan dalam Keputusan Menpan Nomor 84/1993 dan Keputusan Bersama Mendikbud dan Kepala BAKN Nomor 0433/P/1993 dan Nomor 25 Tahun 1993 tentang Jabatan Fungsional Guru dan Angka Kreditnya, serta Keputusan Mendikbud No. 025/P/1995 tentang Petunjuk Teknis Ketentuan Pelaksanaan Jabatan Fungsional Guru dan Angka Kreditnya (Depdikbud, 1995), titik berat upaya peningkatan mutu profesionalisme dan pembinaan karier guru ditekankan pada: (1) Pendidikan/pelatihan;(2) Proses belajar/mengajar/bimbingan; (3) Pengembangan profesi; dan (4) Penunjang proses belajar mengajar/ bimbingan. Ketentuan di atas sehubungan dengan pemikiran tentang pe- ningkatan mutu profesionalisme dan pembinaan karier guru karena jabatan guru adalah jabatan profesional, yang berarti untuk dapat melaksanakan tugas dan tanggung jawabnya dituntut keahlian dan kecakapan khusus yang harus diperoleh melalui pendidikan dan pelatihan.

Tugas dan kewajiban guru dan tenaga kependidikan lainnya adalah mengembangkan kemampuan profesionalismenya. Pengembangan profesi jabatan guru adalah usaha guru dalam rangka mengamalkan ilmu, teknologi, dan ketrampilan untuk meningkatkan mutu proses belajar mengajar bimbingan dan konseling dan profesionalisasi tenaga kependidikan agar dapat memberikan manfaat dan nilai tambah bagi 
pelaksanaan pendidikan dan pengajaran. Dalam pengertian ini, tersirat beberapa aspek, antara lain: (1) kegiatan diarahkan kepada peningkatan mutu pendidikan dan mutu profesi; (2) kegiatan harus dilakukan oleh guru sendiri dan tenaga kependidikan lainnya; (3) ruang lingkup tugas berkenaan dengan tugas dan tanggung jawabnya didasarkan atas ilmu pengetahuan, teknologi dan keterampilan profesional yang disandangnya.

Berdasarkan hal tersebut di atas, tujuan dari pengembangan profesi adalah meningkatkan mutu pendidikan dan pengajaran. Mengacu kepada tujuan tersebut, fungsi pengembangan profesi dalam hubungannya dengan angka kredit fungsional guru tidaklah sematamata untuk mengumpulkan angka kredit dan unsur pengembangan profesi, tetapi lebih penting lagi adalah diperolehnya nilai tambah bagi peningkatan kualitas tugas dan tanggung jawab profesinya dalam meningkatkan mutu pendidikan dan pengajaran.

Pengembangan profesi terdiri atas lima sub unsur pengembangan profesi, yaitu: (1) membuat karya tulis/karya ilmiah; (2) menemukan teknologi tepat guna; (3) membuat alat pelajaran; (4) menciptakan karya seni; dan (5) mengikuti kegiatan pengembangan kurikulum. Di mana unsur-unsur pengembangan profesi ini diakui dan dihargai dalam bentuk angka kredit, yang dapat digunakan untuk kenaikan pangkat dan jabatan fungsional guru dan tenaga kependidikan lainnya (Depdikbud, 1995).

Menurut Depdikbud (1998), khusus untuk karya tulis ilmiah dalam pengembangan profesi adalah mencakup:
(1) karya tulis hasil penelitian, pengkajian, survei dan evaluasi; (2) karya tulis berupa tinjauan atau ulasan ilmiah hasil gagasan sendiri dalam bidang pendidikan, pengajaran, bimbingan, penilaian, dan bidang lainnya; (3) makalah berupa tinjauan atau ulasan ilmiah, gagasan sendiri dalam bidang pendidikan, pengajaran, bimbingan, penilaian dan bidang lainnya; (4) tulisan ilmiah populer dalam media massa; (5) penyampaian makalah dalam bentuk prasaran pada pertemuan ilmiah; (6) buku pelajaran atau modul; dan (7) diktat pelajaran.

Beberapa kemampuan yang dituntut dari guru agar dapat membuat karya tulis ilmiah, antara lain sebagai berikut. Pertama, pengetahuan dasar tentang penulisan ilmiah, baik yang berkenaan dengan teknik penulisan maupun berkenaan dengan notasi ilmiah. Di samping itu, kemampuan menggunakan bahasa tulisan dengan baik dan benar sesuai dengan kaidah-kaidah yang berlaku. Kedua,memiliki wawasan yang luas mengenai pendidikan, pengajaran, bimbingan dan konseling, baik praktek maupun teori. Untuk itu, diperlukan adanya usaha untuk mempelajari buku atau referensi kependidikan serta pengalaman profesional sebagai tenaga guru dan tenaga kependidikan lainnya. Ketiga, pengetahuan dasar mengenai metode penelitian. Untuk itu,guru dituntut mempelajari buku-buku penelitian, membaca hasil penelitian orang lain, diskusi dengan rekan sejawat, dan usaha lain untuk memperkaya diri di bidang penelitian. Keempat, menguasai materi keilmuan atau materi mata pelajaran yang menjadi spesialisasinya 
atau yang diajarkan. Tanpa adanya penguasaan materi tersebut, tidak mungkin guru dapat membuat karya tulis ilmiah, baik berupa makalah, diktat, buku maupun penelitian (Depdikbud, 1998).

Berdasarkan keempat hal di atas, sangat penting adanya dukungan sumber referensi/acuan yang beragam, baik dari sumber yang diperoleh di perpustakaan sekolah, perpusatakaan daerah, toko buku, ataupun sumber yang berasal dari internet. Sumber yang terakhir ini sangat penting karena akan memperluas khasanah ilmu dan pengetahuan guru, kemudahan akses, informasi yang didapat bersifat mutakhir dan mengikuti perkembangan globalisasi.

Karya tulis ilmiah dihargai lebih tinggi daripada bidang proses belajar/ bimbingan, bidang penunjang proses belajar atau bimbingan dan konseling, bahkan dengan unsur pengembangan profesi lainnya. Perimbangan tersebut berkenaan dengan kegiatan atau sifat kegiatan yang dituntutnya, nilai dan manfaatnya, dampak terhadap kualitas profesi yang disandangnya. Karya ilmiah dan unsur lain dari pengembangan profesi lebih bersifat akademis atau mengandung nilai keilmuan dibandingkan dengan bidang kegiatan lainnya, di samping menuntut kreativitas yang tinggi. Mengacu kepada tujuan tersebut, fungsi pengembangan profesi dalam kaitannya dengan angka kredit jabatan fungsional guru tidak sematamata mengumpulkan angka kredit dan unsur pengembangan profesi, telaah yang lebih penting lagi adalah diperolehnya nilai tambah bagi peningkatan kualitas tugas dan tanggung jawab pro- fesinya dalam rangka meningkatkan mutu pendidikan dan pengajaran. Berdasarkan uraian di atas, maka penekanan perhatian terhadap pengembangan profesi khususnya penyusunan karya ilmiah sangat penting.

Secara aktual, di lapangan terlihat bahwa guru dan tenaga fungsional kependidikan lainnya menghadapi kendala yang cukup serius untuk memenuhi persyaratan kenaikan pangkatjabatan dan golomgan IV/a ke IV to ke atas dan unsur pengembangan profesi (minimal 12 angka kredit). Tampak di sekolahsekolah, guru-guru golongan IV/a semakin membengkak, dan dari waktu ke waktu semakin bertambah lagi. Hal semacam ini sudah tentu akan menyebabkan motivasi guru untuk melaksanakan tugasnya dalam proses belajar mengajar/bimbingan dan konseling akan semakin merosot dan apabila hal semacam ini tidak ditangani secara serius, terprogram dan sistematis oleh instansi yang relevan, tidak disangsikan akan menimbulkan gejala apatisme di kalangan para guru dan tenaga fungsional kependidikan lainnya, dan pada akhirnya akan bermuara pada merosotnya mutu pendidikan.

Aktivitas penelitian merupakan hal yang penting dilaksanakan oleh guru dalam rangka pengembangan profesi. Bagi kepentingan ilmu pengetahuan, penelitian merupakan sarana pengembangan ilmu dan teknologi, bagi kepentingan masyarakat penelitian membantu menyelesaikan atau mengurangi permasalahan yang dihadapi masyarakat, dan bagi kepentingan peneliti, penelitian menambah wawasan sebagai seorang guru atau pengawas sekolah, 
yang notabene merupakan agen pengembang ilmu dan teknologi.

Kendala dalam upaya memenuhi persyaratan kenaikan pangkat’jabatan dan golongan, seperti diuraikan di atas, sebagian besar disebabkan oleh kendala rendahnya kemampuan guru-guru dan tenaga fungsional kependidikan lainnya dalam hal melakukan kegiatan karya tulis ilmiah. Hal ini didukung oleh Nilakusmawati, D.P.E. (2008), dalam penelitiannya mengenai faktor-faktor pendukung dan penghambat bagi guru dalam melakukan penelitian untuk penyusunan karya tulis ilmiah dalam rangka pengembangan profesi guru, yang dilakukan di Kabupaten Tabanan dengan mengambil sampel guru-guru negeri (PNS) yang ada di lingkungan pembinaan Dinas Pendidikan Kabupaten Tabanan. Hasil penelitian menunjukkan bahwa lima faktor utama yang menjadi motivasi guru melakukan penelitian dalam menyusun karya tulis ilmiah dalam rangka pengembangan profesi secara berturut-turut adalah: (1) memenuhi rasa ingin tahu; (2) mengumpulkan angka kredit; (3) membantu menyelesaikan permasalahan pendidikan; (4) memenuhi persyaratan unsur pengembangan profesi; dan (5) dorongan dari kepala sekolah dan/atau guruguru senior. Lima faktor utama yang merupakan penghambat, berturut-turut adalah: (1) terbatasnya kemampuan dalam tata tulis ilmiah; (2) sulit memahami acuan bahasa asing; (3) terbatasnya buku referensi/acuan; (4) dana penelitian tidak disediakan oleh sekolah/ kantor; dan (5) kurang siap dengan dasar teori.
Salah satu sub unsur pengembangan profesi bagi guru dan tenaga kependidikan lainnya adalah membuat karya tulis/karya ilmiah, namun dalam kenyataannya di lapangan, guru-guru mengalami hambatan dalam rangka pemenuhan unsur tersebut di atas, yang secara dominan disebabkan oleh kendala terbatasnya bahan referensi/acuan dan kepustakaan. Secara umum, guru hanya memanfaatkan bahan referensi/ acuan yang ada di perpustakaan sekolah masing-masing, ataupun dengan membeli di toko buku. Tidak adanya inisiatif dari guru-guru untuk mencari bahan referensi/acuan dari sumber lainnya, seperti dengan penelusuran di internet. Hal ini disebabkan karena tidak dimilikinya, atau rendahnya kemampuan dari guru-guru, dalam hal ini guru-guru SMP, dalam melalukan penelusuran bahan referensi/acuan dari sumber internet. Penelitian ini bermaksud untuk mengatasi permasalahan mengenai terbatasnya buku referensi/acuan, yang merupakan permasalahan dominan bagi guru-guru dalam melakukan penelitian untuk bahan penulisan karya tulis ilmiah. Dengan dimilikinya kemampuan penelusuran buku referensi/acuan, artikel, jurnal ilmiah, e-book, dan material penunjang lainnya di internet, diharapkan akan dapat memperkaya sumber referensi/acuan bagi guruguru untuk melakukan kegiatan penelitian, yang merupakan sumber bagi penulisan karya tulis ilmiah dalam rangka pengembangan profesi guru, yang akhirnya bermuara pada peningkatan mutu pendidikan nasional.

Berdasarkan uraian di atas, permasalahan dalam penelitian ini sebagai be- 
rikut. Bagaimanakah pengetahuan awal guru-guru SMPN 3 Tabanan, di Kabupaten Tabanan mengenai internet sebagai salah satu sumber referensi (bahan kepustakaan) dalam rangka penyusunan karya tulis ilmiah? Bagaimanakah efektivitas dari pemberian pelatihan penelusuran referensi dari sumber internet dalam meningkatkan pengetahuan guru-guru SMPN 3 Tabanan, di Kabupaten Tabanan tentang cara-cara penelusuran referensi dari sumber internet sebagai bahan kepustakaan dalam rangka penyusunan karya tulis ilmiah?.

Tujuan yang ingin dicapai dari penelitian ini adalah untuk: (1) mengkaji pengetahuan awal guru-guru SMPN 3 Tabanan di Kabupaten Tabanan mengenai internet sebagai salah satu sumber referensi (bahan kepustakaan) dalam rangka penyusunan karya tulis ilmiah; dan (2) mengetahui efektivitas pemberian pelatihan dalam meningkatkan pengetahuan guru-guru SMPN 3 Tabanan di Kabupaten Tabanan tentang caracara penelusuran referensi dari sumber internet. Rumusan hipotesis yang diuji dalam penelitian ini adalah pemberian pelatihan cara-cara penelusuran referensi dari sumber internet efektif untuk meningkatkan pengetahuan guru-guru SMPN 3 Tabanan, Kabupaten Tabanan tentang cara-cara penelusuran referensi dari sumber internet.

Belajar merupakan kegiatan bagi setiap orang. Bagi guru-guru kegiatan belajar ditempuh melalui upaya pendidikan dan pelatihan. Pengetahuan, keterampilan, kebiasaan, kegemaran dan sikap seseorang terbentuk, dimodifikasi dan berkembang disebabkan belajar.
Suryabrata, S. (1983:1) mengemukakan bahwa dalam belajar ditandai dengan adanya tiga ciri, yaitu: (1) belajar merupakan suatu perubahan dalam tingkah laku; (2) belajar merupakan suatu perubahan yang terjadi melalui latihan atau perubahan dalam tingkah laku; (3) belajar merupakan suatu perubahan yang terjadi melalui latihan atau pengalaman; dan (4) untuk dapat dikatakan sebagai belajar, maka perubahan itu harus relatif menetap, yaitu harus merupakan akhir dari suatu periode waktu yang cukup panjang. Sardiman (1994: 23) mengatakan bahwa belajar akan membawa suatu perubahan pada individu-individu yang belajar. Perubahan itu tidak hanya berkaitan dengan penambahan ilmu pengetahuan, tetapi juga berbentuk kecakapan, keterampilan, sikap, pengertian, harga diri, minat, watak, penyesuaian diri. Jelasnya, menyangkut segala aspek organisme dan tingkah laku pribadi seseorang.

Pada intinya, orang yang belajar tidak sama dengan sebelum mereka melakukan perbuatan belajar itu. Dengan demikian, dapat dikatakan bahwa: (1) dalam belajar, faktor perubahan tingkah laku harus ada, tidak dikatakan belajar apabila di dalamnya tidak ada perubahan tingkah laku; (2) perubahan tersebut pada pokoknya didapatkan kecakapan baru; dan (3) perubahan itu terjadi karena perubahan yang disengaja (Sukardi, 1983:19).

Teori belajar yang disusun Gagne merupakan perpaduan yang seimbang antara behaviorisme dan kognitivisme, yang berpangkal pada teori proses informasi (Soekamto, Toeti dan Udin Saripudin Winataputra, 1997: 30). Cara 
berpikir seseorang tergantung pada keterampilan apa yang telah dipunyainya dan keterampilan serta hierarki apa yang diperlukan untuk mempelajari suatu tugas. Selanjutnya, di dalam proses belajar terdapat dua fenomena atau gejala, yaitu: (1) keterampilan intelektual yang meningkat sejalan dengan meningkatnya umur serta latihan yang diperoleh individu; dan (2) belajar akan lebih cepat apabila strategi kognitif dapat dipakai dalam memecahkan masalah secara efisien.

Menurut Gagne (1985), perolehan belajar dikatagorikan menjadi lima macam perolehan, yaitu keterampilan intelektual, strategi kognitif, informasi verbal, sikap, dan keterampilan motorik. Dengan demikian, dapat dinyatakan bahwa dasarnya proses pembelajaran ditandai dengan adanya perubahan perilaku baik yang menyangkut aspek kognitif, afektif, maupun psikomotor. Di mana proses perubahan terjadi dari hal yang paling sederhana sampai pada hal yang paling kompleks.

Dari uraian yang telah diungkapkan di atas, dapat dinyatakan bahwa belajar tidak hanya menerima informasi dan pengalaman baru saja, tetapi juga terjadi penstrukturan kembali informasi dan pengalaman lamanya untuk mengakomodasi informasi dan pengalaman baru.

Hasil belajar dapat didefinisikan sebagai suatu perubahan tingkah laku sesuai dengan petunjuk yang diinginkan. Dalam istilah pendidikan atau pembelajaran, hasil belajar adalah merupakan hasil suatu perubahan respons dengan jenis stimuli tertentu. Istilah hasil belajar sesuai dengan perkembangan- nya berjalan dengan cara-cara yang baru, pertama dengan modifikasi pada model perilaku; dan kedua dikaitkan dengan pembelajaran yang diistilahkan dengan hasil belajar (learning outcome) yang kadang-kadang diterapkan dengan perubahan perilaku (Smith, Fred M. dan Sam Adams, 1972: 89-90).

Berdasarkan beberapa teori belajar di atas, maka diajukan asumsi bahwa proses belajar bagi guru dalam penelitian ini, yaitu melalui pelatihan dapat meningkatkan pengetahuan guru SMP Negeri 3 Tabanan, Kabupaten Tabanan tentang cara-cara penelusuran referensi dari sumber internet.

\section{METODE}

Penelitian ini menggunakan model rancangan penelitian eksperimental, yaitu pre experimental design dengan jenis desain pre test and post test group design. Menurut Campbell dan Stanley (dalam Arikunto, 1999:83), pre experimental design seringkali dipandang sebagai eksperimen yang tidak sebenarnya. Oleh karena itu, sering disebut juga dengan istilah "quasi experiment" atau eksperimen semu. Disebut demikian karena eksperimen jenis ini belum memenuhi persyaratanseperticaraeksperimen yang dapat dikatakan ilmiah yang mengikuti peraturan-peraturan tertentu. Ada 3 jenis yang dimasukkan ke dalam kategori pre experimental design, yaitu (1) one shot case study; (2) pre test and post test; dan (3) static group comparison.

Menurut Arikunto (1999:84), di dalam desain pre test and post test group, observasi dilakukan sebanyak 2 kali yaitu sebelum eksperimen dan sesudah eksperimen. Observasi yang dilakukan 
sebelum eksperimen $\left(\mathrm{O}_{1}\right)$ disebut pre test, dan observasi sesudah eksperimen $\left(\mathrm{O}_{2}\right)$ disebut post test. Perbedaan antara $\mathrm{O}_{1}$ dan $\mathrm{O}_{2}$ yakni $\mathrm{O}_{2}-\mathrm{O}_{1}$ diasumsikan merupakan efek dari treatment atau eksperimen.

Prosedur pelaksanaan eksperimen pada penelitian ini terdiri dari rangkaian kegiatan berupa: pelaksanaan pre test, pemberian perlakuan, dan pelaksanaan post test. Eksperimen ini melibatkan satu kelompok subjek yang memperoleh perlakuan pemberian pelatihan cara-cara penelusuran referensi dari sumber internet, dan sebelum kelompok ini mendapatkan perlakuan terlebih dahulu subjek diberikan pre test.

Penelitian dilakukan di SMPN 3 Tabanan, mulai tanggal 8-10 Oktober 2009, dengan subjek penelitian adalah guru-guru di SMPN 3 Tabanan, Kabupaten Tabanan, yang berjumlah 40 orang. Kegiatan penelitian ini dilaksanakan dalam bentuk pelatihan cara-cara penelusuran referensi/acuan untuk penulisan karya tulis ilmiah, dengan penelusuran dari sumber internet, berupa artikel ilmiah, jurnal ilmiah, e-book, BSE/ Buku Sekolah Elektronik, dan referensi lainnya dari sumber internet. Pelatihan dilakukan dengan metode ceramah dan demonstrasi, dengan memperkenalkan cara-cara penelusuran bahan referensi/ acuan dari sumber internet, dengan memperagakan langkah demi langkah, menggunakan metode presentasi. Materi yang disajikan, meliputi: (1) sekilas tentang internet; (2) teknik dasar pencarian menggunakan Google; dan (3) teknik pencarian lanjutan menggunakan Google, dengan mengacupada sum- ber Wicaksono, Y. (2009) dan Supardi, Y. (2009).

Evaluasi dari pemberian pelatihan, meliputi pemberian pre test tentang pengetahuan awal peserta pelatihan mengenai sumber referensi/acuan yang biasa mereka gunakan, serta pengetahuan awal guru-guru mengenai sumber referensi/acuan dari penelusuran di internet. Setelah diberikan pelatihan caracara penelusuran referensi dari sumber internet akan diberikan evaluasi berupa post test mengenai pengetahuan peserta setelah mendapatkan pelatihan. Pengetahuan awal yang dimaksudkan disini, dituangkan ke dalam item-item kuesioner, meliputi: (1) mengetahui tentang apa itu internet secara umum; (2) pernah memanfaatkan paling sedikit salah satu fasilitas-fasilitas yang ada di internet; (3) pernah membuka paling sedikit salah satu halaman website salah satu situs tertentu; dan (4) pernah menggunakan paling sedikit salah satu mesin pencari (search engine) di internet untuk mencari informasi atau referensi tertentu.

Sebagai indikator keberhasilan kegiatan ini adalah adanya peningkatan pengetahuan guru-guru tentang caracara penelusuran bahan referensi/acuan dari sumber internet. Peningkatan ini dapat dilihat dari hasil analisis data skor pengetahuan peserta pada pre test dan post test.

Teknik analisis data yang digunakan adalah deskritif kualitatif terhadap data yang diperoleh dari hasil observasi, sedangkan analisis data kuantitatif dilakukan terhadap data-data yang berupa angka-angka yang diperoleh dari hasil pre test dan post test. Analisis kuan- 
titatif dalam penelitian ini menggunakan analisis statistika, yaitu statistik deskriptif dan inferensial. Statistik deskriptif dipergunakan untuk melihat sebaran data semua variable penelitian, sedangkan statistik inferensial dipergunakan untuk melihat keterkaitan antar satu variabel dengan variabel lainnya. Hipotesis penelitian diuji dengan uji $t$ untuk dua sampel yang berpasangan (paired sample $t$ test). Uji $\mathrm{t}$ paired berfungsi untuk menguji dua sampel yang berpasangan, apakah mempunyai ratarata yang secara nyata berbeda ataukah tidak (Santoso, S. dan Tjiptono, F., 2001: 161). Analisis data penelitian memanfaatkan software komputer statistik SPSS versi 12.0 for Window, dengan taraf signifikansi sebesar 5\%.

\section{DESKRIPSI PENGETAHUAN AWAL GURU-GURU TENTANG INTERNET SEBAGAI SALAH SATU SUMBER REFERENSI}

Pengetahuan awal guru-guru, untuk item pertanyaan mengenai apa itu internet secara umum, dari 40 orang yang mengikuti pelatihan, terdapat sebanyak 67,5\% yang tidak mengetahui apa itu internet, sedangkan sisanya $32,5 \%$ telah mengetahui apa itu internet. Beberapa dari para guru yang tidak tahu, cenderung memberikan komentar "belum tahu, hanya mendengar saja istilah internet". Jawaban dari peserta ini mengindikasikan bahwa sesungguhnya media internet tersebut sudah begitu sering didengar, namun hanya sebatas pada mendengar istilahnya saja, belum sampai pada tahap dimanfaatkan oleh para guru peserta pelatihan dalam rangka menunjang penulisan karya tulis ilmiah maupun sumber materi tambahan untuk proses belajar mengajar di sekolah.

Item kuesioner yang menanyakan mengenai apakah mereka pernah memanfaatkan paling sedikit salah satu fasilitas-fasilitas yang ada di internet seperti fasilitas email, mailing list, mendownload dari internet, dan fasilitas lainnya, diperoleh bahwa $72,5 \%$ peserta pelatihan menyatakan tidak pernah memanfaatkan fasilitas yang ada di internet, dan hanya 27,5\% yang menjawab pernah. Bagi mereka yang menjawab pernah, fasilitas-fasilitas yang sering mereka pergunakan adalah membuka halaman situs-situs yang menyajikan informasi tentang berita terkini, masakan, dan artis. Mengenai pemanfaatan fasilitas email, dari 40 orang peserta pelatihan, hanya $12,5 \%$ yang mempunyai alamat email, yang berarti secara kasar dapat dikatakan bahwa para guru masih jauh tersentuh oleh teknologi informasi. 
Tabel 1. Pengetahuan Awal Guru-guru Tentang Internet

\begin{tabular}{|c|c|c|c|}
\hline \multirow[t]{2}{*}{ No. } & Pengetahuan Awal Tentang Internet & \multicolumn{2}{|c|}{ Jumlah } \\
\hline & & $\mathrm{N}$ & $\%$ \\
\hline 1. & Mengetahui tentang apa itu internet secara umum & & \\
\hline & - Tidak Tahu & 27 & 67,5 \\
\hline & - Tahu & 13 & 32,5 \\
\hline & Total & 40 & 100,0 \\
\hline 2. & $\begin{array}{l}\text { Pernah memanfaatkan paling sedikit salah satu } \\
\text { fasilitas-fasilitas yang ada di internet }\end{array}$ & & \\
\hline & - Tidak Pernah & 29 & 72,5 \\
\hline & - Pernah & 11 & 27,5 \\
\hline & Total & 40 & 100,0 \\
\hline 3. & $\begin{array}{l}\text { Pernah membuka paling sedikit salah satu halaman } \\
\text { website salah satu situs tertentu }\end{array}$ & & \\
\hline & - Tidak Pernah & 29 & 72,5 \\
\hline & - Pernah & 11 & 27,5 \\
\hline & Total & 40 & 100,0 \\
\hline 4. & $\begin{array}{l}\text { Pernah menggunakan paling sedikit salah satu mesin } \\
\text { pencari (search engine) di internet untuk mencari } \\
\text { informasi atau referensi tertentu }\end{array}$ & & \\
\hline & - Tidak Pernah & 34 & 85,0 \\
\hline & - Pernah & 6 & 15,0 \\
\hline & Total & 40 & 100,0 \\
\hline
\end{tabular}

Sumber: Data Primer, 2009

Jawaban peserta pelatihan mengenai pertanyaan apakah mereka pernah membuka paling sedikit salah satu halaman website salah satu situs tertentu, terdapat $72,5 \%$ menyatakan tidak pernah, dan hanya 27,5\% menyatakan pernah. Sedangkan untuk item kuesioner mengenai pemanfaatan paling sedikit salah satu mesin pencari (search engine) di internet untuk mencari informasi atau referensi tertentu, dijawab tidak pernah oleh sebagian besar peserta pelatihan $(85,0 \%)$, dan hanya $15,0 \%$ yang menyatakan pernah memanfaatkan search engine. Bagi yang menyatakan pernah, sebagian besar memanfaatkan Google dan Yahoo. Secara rinci dis- tribusi jawaban peserta pelatihan disajikan dalam Tabel 1.

\section{EFEKTIVITAS PEMBERIAN PELA- TIHAN DALAM MENINGKATKAN PENGETAHUAN GURU-GURU}

Berdasarkan skor jawaban peserta pelatihan terhadap beberapa pertanyaan dalam pre test dan post test kemudian dikelompokkan ke dalam tiga kategori yaitu: (1) Baik, (2) Cukup, dan (3) Kurang, dengan maksud untuk lebih memudahkan deskripsi. Dikategorikan Baik apabila hampir semua pertanyaan yang menyangkut pengetahuan peserta pelatihan tentang penelusuran referensi dari sumber internet dapat terjawab hampir sempurna. Kategori Cukup, 
apabila ada beberapa pertanyaan yang tidak dapat terjawab dengan baik, dan kategori kurang bila hampir semua pertanyaan tidak dapat dijawab dengan baik oleh peserta pelatihan.

Hasil analisis deskriptif terhadap skor pre test diperoleh bahwa dari 40 orang guru yang mengikuti pelatihan terdapat 1 orang guru $(2,5 \%)$ dalam kategori baik, 13 orang guru $(32,5 \%)$ dalam kategori cukup dan 26 orang guru $(65,0 \%)$ dalam kategori kurang. Untuk mengetahui apakah pelatihan yang diberikan tersebut memberikan manfaat pada guru-guru mengenai pengetahuannya tentang cara-cara penelusuran referensi di internet, maka pada akhir pelatihan diberikan post test. Kategori hasil post test menunjukkan bahwa setelah mengikuti pelatihan, tidak ada guru yang mempunyai pengetahuan tentang penelusuran referensi di internet dalam kategori kurang, 19 guru $(47,5 \%)$ berada dalam kategori baik dan 21 orang guru (52,5\%) berada dalam kategori cukup.

Hasil analisis tabulasi silang antara hasil pre test dan post test ditunjukkan pada Tabel 2, terlihat bahwa dari 13 orang yang nilai pre testnya dalam kategori cukup, ada 12 orang meningkat post testnya menjadi kategori baik. Dari 26 orang guru yang nilai pre testnya dalam kategori kurang, terdapat 20 orang yang meningkat menjadi kategori cukup pada hasil post testnya dan 6 orang dalam kategori baik.

Tabel 2. Tabulasi Silang Antara Pre Test dan Post Test

\begin{tabular}{ccccc}
\hline Pre Test & \multicolumn{3}{c}{ Post Test } & \multicolumn{2}{c}{ Jumlah } \\
\cline { 2 - 5 } & Baik & Cukup & $\mathrm{N}$ & $\%$ \\
\hline Baik & 1 & 0 & 1 & 2,5 \\
Cukup & 12 & 1 & 13 & 32,5 \\
Kurang & 6 & 20 & 26 & 65,0 \\
Total (N) & 19 & 21 & 40 & 100,0 \\
$\%$ & 47,5 & 52,5 & & \\
\hline
\end{tabular}

Sumber: Data Primer, 2009

Tabulasi silang antara pre test dan post test menjelaskan bahwa pemberian pelatihan dapat meningkatkan pengetahuan peserta pelatihan tentang penelusuran referensi dari sumber internet, dari yang semula dalam kategori cukup menjadi baik, dan dari kategori kurang menjadi kategori cukup dan baik.

Pengujian hipotesis penelitian diuji dengan menggunakan uji hipotesis beda dua mean untuk observasi berpasangan, yaitu uji t (paired sample t test).
Uji t ini biasanya, atau dalam prakteknya digunakan untuk banyaknya pasangan pengamatan $<30$, tetapi tidak tertutup kemungkinan pemakaiannya untuk kasus banyaknya pasangan pengamatan $\geq 30$. Dalam kasus penelitian ini, banyaknya pasangan pengamatan adalah 40 , dan ditetapkan untuk menggunakan uji $\mathrm{t}$ (paired sample $t$ test). Menurut Djarwanto, Ps. (1996: 134), uji t dipergunakan untuk kasus yang observasinya dilakukan dua kali terhadap 
subyek yang sama atau sampel yang sama. Kadangkala disebut dua sample dependent, dan dapat dipakai dalam desain "Before-After" dalam studi eksperimen.

Tujuan dari pengujian hipotesis dalam penelitian ini adalah untuk me- nyimpulkan apakah pemberian pelatihan dapat memberikan peningkatan yang signifikan terhadap pengetahuan guru-guru peserta pelatihan mengenai cara-cara penelusuran referensi/acuan dari sumber internet sebagai bahan penulisan karya tulis ilmiah atau tidak.

Tabel 3. Paired Samples Statistics

\begin{tabular}{llllcc}
\hline & Mean & N & Std. Deviation & Std. Error Mean \\
\hline Pair & Pre Test & 4,538 & 40 & 1,4909 &, 2357 \\
1 & Post Test & 6,925 & 40 & 1,3893 &, 2197 \\
\hline
\end{tabular}

Sumber: Hasil Analisis Data Primer, 2009

Hasil analisis data pada Tabel 3 menunjukkan rata-rata skor peserta pelatihan sebelum tindakan (pre test) adalah 4,538 , dan rata-rata skor setelah mendapatkan pelatihan (post test) adalah 6,925 . Nilai korelasi antara skor sebelum mendapat pelatihan dengan skor setelah mendapatkan pelatihan sebesar 0,732, dengan probabilitas 0,000 (di bawah 0,05$)$. Hal ini berarti terdapat korelasi yang positif dan berkorelasi secara nyata antara skor sebelum diberi- kan pelatihan dengan skor setelah diberikan pelatihan.

Hasil pengujian hipotesis menggunakan uji $\mathrm{t}$ (Tabel 4), diperoleh nilai $\mathrm{t}$ hitung adalah -4,258 dengan probabilitas 0,000. Karena probabilitas <0,05, maka Ho ditolak, berarti bahwa pemberian pelatihan memberikan peningkatan yang signifikan terhadap pengetahuan guru-guru peserta pelatihan mengenai cara-cara penelusuran referensi/ acuan dari sumber internet, sebagai bahan penulisan karya tulis ilmiah.

Tabel 4. Paired Samples Test

\begin{tabular}{|c|c|c|c|}
\hline & & & Pair 1 \\
\hline & & & Pre Test - Post Test \\
\hline Paired & Mean & & -2.3875 \\
\hline & Std. Deviation & & 1.0591 \\
\hline & Std. Error Mean & & .1675 \\
\hline & $95 \%$ Confidence Interval of the Difference & Lower & -2.7262 \\
\hline & & Upper & -2.0488 \\
\hline $\mathrm{t}$ & & & -14.258 \\
\hline $\mathrm{df}$ & & & 39 \\
\hline Sig. (2-tailed) & & & .000 \\
\hline
\end{tabular}

Sumber: Hasil Analisis Data Primer, 2009 
Hasil analisis menunjukkan terdapat perbedaan yang signifikan antara hasil pre test dan post test, dimana hasil post test lebih besar dari hasil pre test. Hal ini menunjukkan bahwa pemberian pelatihan cara-cara penelusuran referensi di internet yang dilaksanakan di SMP Negeri 3 Tabanan, memberikan manfaat yang signifikan bagi peningkatan pengetahuan guru-guru tentang cara-cara penelusuran referensi/acuan dari sumber internet, sebagai bahan penulisan karya tulis ilmiah.

\section{KESIMPULAN}

Berdasarkan hasil penelitian dan pembahasan di atas, dapat disimpulkan hal-hal sebagai berikut.

- Deskripsi mengenai pengetahuan awal guru-guru tentang internet, diperoleh bahwa: (a) untuk item pertanyaan mengenai apa itu internet secara umum, dari 40 orang yang mengikuti pelatihan, terdapat $67,5 \%$ yang tidak mengetahui apa itu internet, dan 32,5\% telah mengetahui apa itu internet; (b) item kuesioner yang menanyakan mengenai apakah mereka pernah memanfaatkan paling sedikit salah satu fasilitas-fasilitas yang ada di internet, diperoleh $72,5 \%$ peserta pelatihan menyatakan tidak pernah memanfaatkan fasilitas yang ada di internet, dan hanya 27,5\% yang menjawab pernah. Mengenai pemanfaatan fasilitas email, dari 40 orang peserta pelatihan, hanya $12,5 \%$ yang mempunyai alamat email; (3) Jawaban peserta pelatihan mengenai pertanyaan apakah mereka pernah membuka paling sedikit salah satu halaman website salah satu situs tertentu, terdapat $72,5 \%$ menyatakan tidak pernah, dan hanya $27,5 \%$ menyatakan pernah; dan (4) Untuk item kuesioner mengenai pemanfaatan paling sedikit salah satu mesin pencari (search engine) di internet untuk mencari informasi tertentu atau referensi tertentu, dijawab tidak pernah oleh $85,0 \%$ peserta pelatihan, dan hanya $15,0 \%$ yang menyatakan pernah.

- Hasil analisis data secara inferensia, diperoleh rata-rata skor pre test adalah 4,538, dan rata-rata skor post test adalah 6,925. Nilai korelasi antara skor pre test dengan skor post test adalah 0,732, dengan probabilitas 0,000. Berarti bahwa terdapat korelasi yang positif dan berkorelasi secara nyata antara skor sebelum diberikan pelatihan dengan skor setelah diberikan pelatihan.

- Hasil pengujian hipotesis tindakan dengan uji t (paired sample $t$ test), diperoleh nilai $\mathrm{t}$ hitung -14,258 dengan probabilitas 0,000 , sehingga $\mathrm{Ho}$ ditolak. Berarti bahwa pemberian pelatihan efektif untuk meningkatkan pengetahuan guru peserta pelatihan mengenai cara-cara penelusuran referensi/acuan dari sumber internet, sebagai bahan penulisan karya tulis ilmiah.

\section{SARAN}

Berdasarkan hasil yang diperoleh dari penelitian ini, saran yang perlu dipertimbangkan, adalah: sangat perlu dilakukan pelatihan yang serupa dengan lebih intensif, serta mengambil khalayak sasaran para guru-guru SMP. 
Hal ini dimaksudkan untuk memeratakan teknologi informasi di kalangan guru/tenaga kependidikan, memperkaya pengetahuan guru-guru tentang perkembangan ilmu pengetahuan, teknologi, dan penelitian yang mutakhir/terkini dan yang sedang berkembang, yang berdampak positif pada peningkatan kualitas bahan ajar, kualitas mengajarnya dan akhirnya bermuara pada peningkatan kualitas peserta didik.

\section{UCAPAN TERIMA KASIH}

Hasil penelitian tidak akan bermanfaat jika tidak seorang pun mengetahuinya. Oleh karena itu, pada kesempatan ini kami mengucapkan terima kasih kepada tim Redaktur dan staf Jurnal Cakrawala Pendidikan Universitas Negeri Yogyakarta yang telah memberi kesempatan untuk mempublikasikan artikel hasil penelitian ini.

\section{DAFTAR PUSTAKA}

Arikunto, Suharsimi. 1999. Prosedur Penelitian Suatu Pendekatan Praktek. Jakarta: Rineka Cipta.

Depdikbud. 1995. Kepmendikbud Nomor 025/P/1995 tentang Juknis Ketentuan Pelaksanaan Jabatan Fungsional Guru dan Angka Kreditnya. Jakarta: Direktorat Tenaga Kependidikan.

1998. Pedoman Penyusunan Karya Tulis Ilmiah di Bidang Pendidikan dan Angka Kredit Pengem- bangan Profesi Guru. Jakarta: Direktorat Dikgutentis.

Djarwanto, Ps. 1996. Mengenal Beberapa Uji Statistik dalam Penelitian. Yogyakarta: Liberty.

Gagne, R.M. 1985. The Condition of Learning and theory of Instruction. Fourth Edition. New York: Holt, Rinehart and Winston.

Nilakusmawati, D.P.E. 2008. "Analisis Faktor-faktor Pendukung dan Penghambat Bagi Guru Dalam Melakukan Kegiatan Karya Tulis Ilmiah dalam Rangka Pengembangan Profesi Guru". Jurnal Ilmu Pengetahuan Sosial, Vol. X No. 3, Hal. 186-203.

Santoso, Singgih dan Tjiptono, Fandy. 2001. Riset Pemasaran, Konsep dan Aplikasi dengan SPSS. Jakarta: PT. Elex Media Komputindo.

Sardiman, A.M. 1994. Interaksi dan Motivasi Belajar Mengajar. Jakarta: PT. Raja Grafindo Persada.

Smith, Fred M. \& Sam Adams. 1972. Educational Measuremen for The Classroom Teacher. New York: Harper \& Row, Publisher.

Soekamto, Toeti dan Winataputra, Udin Saripudin. 1997. Teori Belajar dan Model-model Pembelajaran. Jakarta: Depdikbud. 
Sukardi., Dewa Ketut. 1983. Bimbingan dan Penyuluhan Belajar di Sekolah. Surabaya: Usaha Nasional.

Supardi, Yuniar. 2009. Internet untuk Segala Kebutuhan. Jakarta: PT. Elex Media Komputindo.
Suryabrata, Sumadi. 1983. Cara-cara Belajar Yang Efisien. Jakarta: Depdikbud.

Wicaksono, Yudhy. 2009. Mencari Berbagai Hal di Internet. Jakarta: PT. Elex Media Komputindo. 